\title{
Anatomical studies of Sphagneticola trilobata (L.) Pruski. (Asteraceae)
}

\section{Sangeeta S Sutar ${ }^{1}$ and Momin Nishat Parveen ${ }^{2 *}$}

${ }^{1}$ Department of Botany, Sir Sayyed College, Aurangabad, Maharashtra, India. ${ }^{2}$ Department of Chemistry, Sir Sayyed College, Aurangabad, Maharashtra, India.

\begin{abstract}
Sphagneticola trilobata (L.) Pruski is a perennial herb, it belongs to the tribe Heliantheae of family Asteraceae. S. trilobata has traditionally been used to treat infections, indigestion and hepatitis; it shows antibacterial, antifungal activity (1). To standardize and differentiate the species anatomical features such as anatomy of nodes, petioles and leaves and dermatological parameters were screened. In addition to these parameters the species were screened phyto-chemically for major chemical groups such as volatile oil, starch, proteins, tannin, saponins, fats, glucosides and alkaloids.
\end{abstract}

Keywords: Morphology, Pharmacognosy, Sphagneticola trilobata, Asteraceae.

\section{Introduction}

S trilobata belongs to the tribe Heliantheae of the Asteraceae. It is commonly known as Bay Biscayne creeping-oxeye. It is a spreading mat forming perennial herb having rounded stem rooting at nodes and serrate or irregularly toothed fleshy leaves. The flowers are bright yellow coloured ray florets. It is mostly propagates vegetatively. Sphangneticola trilobata has traditionally been used to treat infections, indigestion and hepatitis.

\footnotetext{
*Address of Correspondence: Dr. Momin Nishat Parveen, Department of Chemistry Sir Sayyed College Aurangabad, Maharashtra India.

E mail ID: dr.nishatparveen11@gmail.com

(Received 18 December 2019; revised 12 January 2020; accepted 18 January 2020).
}

Due to presence of active chemicals such as nhexane. Ethyl extract of Sphagneticola trilobata shows antibacterial activity. It also have anti-inflammatory, antimicrobial and analgesic property for which it is used to treat symptoms of cold and flu for fever and inflammation.

Traditionally the leaves are used in the treatment of piles. Studies on the pharmacological $(1,2)$ and primary photochemical activity (3) of $S$. trilobata has been reported earlier (4-10).

\section{Materials and Methods}

Anatomical studies: For the present study fresh plants of Sphagneticola trilobata were collected from Nandanvan Colony Aurangabad and preserved in $70 \%$ alcohol (4). Transverse section of nodes, petioles and leaf lamina were taken by free hand method, fresh material were used for nodal anatomy. The peels for epidermal studies were taken 
from fresh material, epidermal peels were stained in $1 \%$ safranin and mounted in glycerin and made semi-permanent slides. The leaves were cleared in $20 \% \mathrm{KOH}$ solution. These were stained with camel pad ink and also dehydrated. All the material was mounted in DPX or Canada balsam and then camera Lucida drawings were made.

\section{Phytochemical studies}

For phytochemical analysis fresh plant material was subjected to various tests according to Gurr (1965) and Johanson $(1940)(11,12)$.

\section{Observations}

\section{Anatomical studies}

Node: The leaves are opposite at the nodal region, the stellar structure shows a prominent an arc shaped trace leaving behind gap.

The main trace and two small lateral traces enter into the petiole.

Petiole: The Petiole is triangular in shape with two wings. The epidermal cells are small and thick walled with cuticle.
The hypodermis is one to two layered collenchymatous and is followed by parenchymatous cortex, intercellular spaces occur in the parenchyma.

Vascular bundles are three in number and unequal in size large median an arc shaped strand is centrally located and two smaller are lateral.

Leaf: The leaf is dorsiventral and amphistomatic. Ad axial epidermis is of large unequal cells. The biaxial epidermal cells are comparatively small; the stomata are present on both the surfaces. They are more in number then lower epidermis.

Mesophyll is differentiated into a palisade and spongy tissue. The palisade is 2-3 layered and spongy tissue is of loosely arranged cells.

The vascular bundles are collateral with xylem oriented towards upper side. The bundle sheath is present.

Epidermis: The leaves are amphistomatic, the numbers of stomata is less on the uppers surface as compared to lower surface. The stomata are anomocytic type. Glandular hairs are common.

Table No 1: Phytochemical analysis

\begin{tabular}{|c|c|c|c|}
\hline Test & Stem & Root & Leaves \\
\hline Starch & + & + & + \\
\hline Proteins & + & - & + \\
\hline Tannins & + & - & + \\
\hline Saponins & + & - & + \\
\hline Fats & + & - & + \\
\hline Glycosides & + & + & + \\
\hline Alkaloids & & & + \\
\hline
\end{tabular}




\section{Discussion and Conclusions}

Studies on Sphagneticola trilobata (L.) Pruski shows that it is very safe drug for various diseases it is popular among the various traditional drugs, anatomical studies reveals that petiole is triangular in outline, leaf is dorsiventral and amphistomatic and stomata are anomocytic type. In earlier studies only phytochemical studies were carried out, in the present paper anatomical and some vegetative phytochemical analysis has been carried out.

Phytochemical studies reveals that starch, proteins and alkaloids are present in root, Tannins, saponins and fats present in stem and leaves, absent in root and glycosides present in leaf and absent in stem and root. It is necessary to introduce drugs of plant origin which are safe for human being and do not cause side effects.

\section{Acknowledgement}

Nil.

\section{Disclosure}

The authors report no conflicts of interest in this work. No violation of human rights and safety.

\section{References}

1. Neelam Balekar, Titpawan Nakphang, Teerapol Srichana. Wadelia trilobata L. A Phytochemical and pharmacological review. Ching Mai J. Sci. 2014; 41(3: )590605.

2. Nithin Manohar R, Padmaja V, Shijikumar PS, Shiji Selvin $\mathrm{CD}$, Ancy P. Comparing the pharmacological activities of Sphagneticolacalendulaceae and Sphagneticola trilobata an over view. World Journal of pharmacy and pharmaceutical Sciences. 2011; 6: 457-467.

3. Sushama Raj RV. Primary phytochemical investigation of Sphagneticola trilobata(L.) Pruski. J. of Pharmacognosy and phytochemistryvol. 2019; 8(1): 968-971.

4. Metcalf CR, Chalk L. Anotomy of the Dicotyledonf-II Clarendon press Oxford. 1950.

5. Sutar SS, Ahuja SR. NishatParveen. Pharanacognostic studies of Kickxiaromosissima (Wall.) Janchen (Scrophulariacese). Genius. 2014. Vol. II. 74-78.
6. Sutar SS. Pharmacognostic studies of Verbascumchinense (L.) Santapau (Scrophulariaceae) Genius. 2014;Vp;-III 38-42.

7. Sutar SS, Dharasurkar AN. Pharmacognostic studies of Bacopamonneri (L.) Pennell (Scrophulariaceae). Bioinfolet. 2015; 12(2A): 359-361.

8. Dharasurkar AN, Sutar SS. Pharmacognostic, epidermal and leaf architectural studies in OcimumkilimandschariumGuerke(Lamiaceae). Bioinfolet. 2015; 12 (2A): 354358.

9. Sutar SS, Pathak SS. Pharamacognostic studies Alternantherapungens H.B. \& K. (Amaranthaceae). Bioinfolet. 2016; 13(1b): 110-111.

10. Dharasurkar AN, Sutar SS. Pharmacognostic evaluation of Oxalis corniculata L (Oxalidaceae). Science research reporter. 2016; 6(1): 63-67.

11. Gurr E. The rational use of Dyes in Biology \& general staining Methods. Leonard Hill, London. 1965.

12. Johansen DA. Plant Microtechnique, Tata McGraw, HillPublishing Company Ltd, New Delhi. 1940.

International Research Journal of Multidisciplinary Scope (IRJMS) 